\title{
Efficient Evaluation of Resistance to Three Root-knot Nematode Species in Selected Sweetpotato Cultivars
}

\author{
J.C. Cervantes-Flores and G.C. Yencho ${ }^{1}$ \\ Department of Horticultural Science, North Carolina State University, \\ Raleigh, NC 27695
}

E.L. Davis

Department of Plant Pathology, North Carolina State University, Raleigh, NC 27695

Additional index words. Ipomoea batatas, Meloidogyne arenaria, Meloidogyne incognita, Meloidogyne javanica, host plant resistance, plant breeding

\begin{abstract}
Five sweetpotato [Ipomoea batatas (L.) Lam.] cultivars ('Beauregard', 'Excel', 'Jewel', 'Hernandez', and 'Porto Rico') were evaluated for resistance to three root-knot nematode species: Meloidogyne arenaria (Neal) Chitwood (race 2), M. incognita (Kofoid \& White) Chitwood (race 3), and M. javanica (Treub) Chitwood. Resistance screening efficiency was assessed in both $400-\mathrm{cm}^{3}$ square pots and $150-\mathrm{cm}^{3}$ Conetainers ${ }^{\mathrm{TM}}$. Nematode infection was assessed as the percentage of root system galled, percentage of root system necrosis, and the number of nematode eggs produced per gram of root tissue. Means of these dependent variables were not different $(P \leq 0.05)$ between container types, with Conetainers ${ }^{\mathrm{TM}}$ being more efficient to use. Root necrosis was not related to nematode infection, but was significant among cultivars $(P=0.0005)$. The resistance responses of the cultivars differed depending on the nematode species. All five cultivars were resistant to $M$. arenaria race 2. 'Hernandez', 'Excel', and 'Jewel' were also resistant to $M$. incognita race 3 and $M$. javanica.
\end{abstract}

Plant-parasitic nematodes, especially rootknot nematodes (RKN), Meloidogyne species, represent a significant problem in sweetpotato production, causing reduction in yield and quality of storage roots in Asia, South America, and the southern United States (Clark et al., 1992; Sasser and Carter, 1985; Ukoskit et al., 1997). The average damage to field crops by plant-parasitic nematodes is estimated at $10 \%$ worldwide (Whitehead, 1998). Three species of RKN (Meloidogyne incognita, M. arenaria, and $M$. javanica) are particularly important pathogens of sweetpotato (Sasser, 1980). The most characteristic symptoms of RKN are round to spindle-shaped swellings (galls) on fibrous roots and cracks on fleshy storage roots (Lawrence et al., 1986). Nematode injury inflicted during early root development often predisposes storage roots to the formation of cracks in the cortex (Thomas and Clark, 1983a), a major determinant of decreased root quality.

\footnotetext{
Received for publication 3 Dec. 2000. Accepted for publication 4 June 2001. This paper is a portion of a thesis submitted by J.C. C-F. The research reported in this publication was supported by funding from the North Carolina Crop Improvement Association, the North Carolina Sweetpotato Commission, the North Carolina Foundation Seed Producers Association and the Fulbright Commission. We thank William Swallow for his statistical guidance, Rebeca Rufty for her valuable discussions, and Ken Pecota and Cindy Pierce for their assistance with the greenhouse work.

${ }^{1}$ To whom reprint requests should be addressed.
} E-mail: Craig_Yencho@ncsu.edu species of Meloidogyne was assessed in several commercial sweetpotato cultivars in two greenhouse screening systems in this study.

\section{Materials and Methods}

Five sweetpotato cultivars ['Beauregard' (Rolston et al., 1987), 'Hernandez' (LaBonte et al., 1992), 'Jewel' (Pope et al., 1971), 'Porto Rico' (Nielsen and Pope, 1960), and 'Excel' (Jones et al., 1989)] with reported resistance to M. incognita (Clark et al., 1992; Thies, 1999) were evaluated for resistance to $M$. arenaria race 2, $M$. incognita race 3 and $M$. javanica. Fifteen-cm-long cuttings were planted in both $400-\mathrm{cm}^{3}$ pots, model LAPOT (Landmark Plastic Corp., Orlando, Fla.), and $150-\mathrm{cm}^{3}$, model SC-10; Super Cell Conetainers ${ }^{\mathrm{TM}}$ (Stuewe \& Sons, Corvallis, Ore.), containing a pasteurized mix (by volume) of 3 coarse sand : 1 field soil (loamy sand: $88.9 \%$ sand, $8.3 \%$ silt, and $2.8 \%$ clay), respectively.

Each treatment combination (container type, nematode species, and sweetpotato cultivar) was replicated five times, and the same experiment was conducted at two different times. All experiments were arranged in a split-plot design with container type as the main treatment and nematode species as the subplot treatment. Sweetpotato cultivars were distributed randomly within each subplot, and the five replicates of each cultivar were considered subsamples.

Meloidogyne arenaria race 2, M. incognita race 3 , and $M$. javanica were cultured on roots of 'Rutgers' tomato plants (Lycopersicon esculentum Mill.). Eggs of the RKN populations were extracted using Hussey and Barker's (1973) $\mathrm{NaOCl}$ extraction technique and $\approx 10,000$ eggs of the corresponding nematode were injected into the soil to infest each plant. The inoculation was done two weeks after planting each cutting. Inoculated plants were grown under greenhouse conditions of $25^{\circ} \mathrm{C}$ to $28^{\circ} \mathrm{C}$ and watered once a day.

Plants were harvested $56 \mathrm{~d}$ after inoculation and rated visually for the percentages of total root system that were galled or necrotic. Root fresh weights were recorded at harvest. Eggs of RKN were extracted from a maximum of $5 \mathrm{~g}$ of each root system with $\mathrm{NaOCl}$ (Hussey and Barker, 1973). A subsample of the extracted eggs was stained with acid fuchsin (Daykin and Hussey, 1985), and eggs were counted using a stereoscopic microscope to estimate total eggs per gram of root system based upon total root fresh weight.

Nematode data were transformed by log $(\mathrm{x}+1)$ to standardize the variance. All data were subjected to analysis of variance (ANOVA) using the SAS GLM Procedure (SAS Institute, Cary, N.C.). Main effects and interactions were analyzed for all dependent variables mentioned above. To simplify the statistical analysis, and to prevent variations due to missing data, the ANOVA was performed on the means of the five plants for each cultivar within each subplot, with the two experiments serving as replications. Fisher's LSD procedure $(\alpha=0.05)$ was used to compare treatment means. Since no signifi- 
cant differences $(P \leq 0.05)$ in root necrosis, root galling, or nematode egg production were observed between the two container types, data of the square pots and Conetainers ${ }^{\mathrm{TM}}$ were pooled for statistical analyses of sweetpotato response to nematode infection. Back-transformed data are presented in Table 1 for clarity.

\section{Results and Discussion}

The results of these tests indicate that the response of the sweetpotato cultivars evaluated differs among the Meloidogyne species studied. Our results are similar to those observed on other sweetpotato germplasm by Bonsi and Phills (1979). Even though no differences were observed in root necrosis, root galling, and nematode egg production between the two types of containers, some effect (i.e., variations in the shape and density of the roots) in the growth of the root system was visible between the two types of containers, but this did not affect the resistance rating between containers (Table 1).

The differences observed in root system development among cultivars grown in the Conetainers $^{\mathrm{TM}}$ vs. the square pots was largely due to differences in pot shape and volume. But, the difference in root development between containers did not affect RKN infection, even though the roots in the Conetainers ${ }^{\mathrm{TM}}$ tended to be thicker, longer, and less dense than those formed in the square pots. The different root growth pattern observed in the Conetainers $^{\mathrm{TM}}$ made the resistance assessment of the plants easier and faster compared to those grown in the square pots. This characteristic could be used to the advantage of researchers when screening large numbers of breeding lines or accessions for nematode resistance.

The ANOVA on all three nematode species demonstrated significant interactions between cultivar and RKN species $(P<0.0001)$ for root galling and number of eggs per gram of root, but not for root necrosis. Root necrosis was not correlated $(r=0.2)$ with the number of eggs per gram of root, but root necrosis values were significantly different among cultivars $(P=0.0007)$ (Table 1$)$. For example, 'Porto Rico' exhibited a higher degree of necrosis ( $>8 \%$ ), compared to the other four cultivars.

The number of nematode eggs produced per gram of root tissue was highly correlated $(r=0.9)$ with galling. Differences in the level of resistance to the RKN reproduction were observed among the sweetpotato cultivars tested. The numbers of eggs per gram of root system produced by $M$. incognita race 3 were higher in 'Beauregard' (1,214 eggs) and in 'Porto Rico' (1,571 eggs), than in the other three cultivars $(\approx 20$ eggs). Meloidogyne javanica was highly virulent on 'Beauregard', producing over 5,000 eggs per gram of root system. Meloidogyne javanica formed significantly fewer eggs in 'Jewel' (55 eggs per gram of root system), but did not affect 'Excel', 'Hernandez', or 'Porto Rico'. Meloidogyne incognita race 3 caused significant galling in 'Porto Rico' and 'Beauregard', but not in the

Table 1. Root necrosis, root galling, and eggs produced by Meloidogyne arenaria race 2, M. incognita race 3 , and $M$. javanica on selected sweetpotato cultivars in two container types.

\begin{tabular}{|c|c|c|c|c|c|c|c|c|c|}
\hline \multirow[b]{2}{*}{ Cultivar } & \multicolumn{3}{|c|}{ Necrosis $^{\mathrm{z}}$} & \multicolumn{3}{|c|}{ Galling $^{\mathrm{y}}$} & \multicolumn{3}{|c|}{ Eggs/gx } \\
\hline & $\operatorname{Pot}^{\mathrm{w}}$ & Cone $^{v}$ & Mean & Pot & Cone & Mean & Pot & Cone & Mean \\
\hline \multicolumn{10}{|c|}{ M. arenaria race 2} \\
\hline Beauregard & 2 & 5 & $3 \mathrm{a}^{\mathrm{u}}$ & 0 & 0 & $0 \mathrm{a}$ & 0 & 1 & $1 \mathrm{a}$ \\
\hline Excel & 3 & 4 & $3 \mathrm{a}$ & 0 & 0 & $0 \mathrm{a}$ & 1 & 3 & $2 \mathrm{a}$ \\
\hline Hernandez & 1 & 5 & $3 a$ & 0 & 0 & $0 \mathrm{a}$ & 0 & 1 & $0 \mathrm{a}$ \\
\hline Jewel & 3 & 1 & $2 \mathrm{a}$ & 0 & 0 & $0 \mathrm{a}$ & 0 & 5 & $2 \mathrm{a}$ \\
\hline Porto Rico & 6 & 7 & $6 \mathrm{a}$ & 0 & 0 & $0 \mathrm{a}$ & 0 & 1 & $1 \mathrm{a}$ \\
\hline \multicolumn{10}{|c|}{ M. incognita race 3} \\
\hline Beauregard & 2 & 2 & $2 \mathrm{~b}$ & 10 & 15 & $12 \mathrm{a}$ & 2265 & 554 & $1215 \mathrm{a}$ \\
\hline Excel & 2 & 2 & $2 b$ & 0 & 0 & $0 \mathrm{~b}$ & 2 & 1 & $1 \mathrm{c}$ \\
\hline Hernandez & 1 & 1 & $1 \mathrm{~b}$ & 0 & 1 & $0 \mathrm{~b}$ & 24 & 19 & $21 \mathrm{~b}$ \\
\hline Jewel & 3 & 2 & $2 \mathrm{~b}$ & 1 & 1 & $1 \mathrm{~b}$ & 2 & 10 & $5 \mathrm{bc}$ \\
\hline Porto Rico & 12 & 14 & $13 \mathrm{a}$ & 25 & 18 & $20 \mathrm{a}$ & 2565 & 963 & $1572 \mathrm{a}$ \\
\hline
\end{tabular}

\begin{tabular}{lrllrrrrrr} 
& \multicolumn{8}{c}{ M. javanica } \\
Beauregard & 5 & 4 & $5 \mathrm{ab}$ & 25 & 16 & $20 \mathrm{a}$ & 6721 & 4373 & $5421 \mathrm{a}$ \\
Excel & 3 & 1 & $2 \mathrm{c}$ & 0 & 0 & $0 \mathrm{~b}$ & 0 & 1 & $1 \mathrm{c}$ \\
Hernandez & 3 & 2 & $3 \mathrm{bc}$ & 0 & 0 & $0 \mathrm{~b}$ & 0 & 1 & $1 \mathrm{c}$ \\
Jewel & 4 & 1 & $2 \mathrm{bc}$ & 0 & 0 & $0 \mathrm{~b}$ & 55 & 54 & $55 \mathrm{~b}$ \\
Porto Rico & 10 & 4 & $6 \mathrm{a}$ & 0 & 0 & $0 \mathrm{~b}$ & 1 & 1 & $1 \mathrm{c}$
\end{tabular}

${ }^{z}$ Necrosis values are the mean of two replications of five plants each. It is expressed as the percentage of necrotic root tissue. Values were not different between types of container $(P \leq 0.05)$.

${ }^{y}$ Galling values in pot and cone are the mean of two replications of five plants each. It is expressed as the percent of roots galled. Values were not different between types of container $(P \leq 0.05)$.

${ }^{\mathrm{x}} \mathrm{Eggs} / \mathrm{g}$ values are the mean of two replications of five plants each. It is expresed as the number of eggs found per gram of root tissue. Values were not different between types of container $(P \geq 0.05)$.

${ }^{\text {w}}$ Pot, represents the 400- $\mathrm{cm}^{3}$ container, model LAPOT (Landmark Plastic Corp., Orlando, Fla.).

${ }^{\mathrm{v}}$ Cone represents the $150-\mathrm{cm}^{3}, \mathrm{SC}-10$ Super Cell Contetainer ${ }^{\mathrm{TM}}$ (Stuewe \& Sons, Corvalis, Ore.).

"For each root knot nematode species, values within a column followed by the same letter are not different (Fisher's protected LSD test $(\alpha=0.05)$. Transformation of the data used for corresponding ANOVA was $\log (\mathrm{x}+1)$. Back-transformed data are presented in the table.

other three cultivars (Table 1). Meloidogyne javanica produced significant galling only in 'Beauregard' (20\% of root system galled). 'Excel', 'Jewel', 'Hernandez', and 'Porto Rico' were resistant to the formation of galls by $M$. javanica (Table 1). All sweetpotato cultivars evaluated in this experiment were resistant to $M$. arenaria race 2 , which did not produce galls or eggs in the root system.

The data suggest the presence of different genes for resistance in this crop to the different root-knot nematode species, and this is supported by the differences in cultivar pedigree. For example, both 'Excel' and 'Hernandez' are resistant to $M$. incognita race 3 and $M$. javanica, but they have different pedigrees. The difference in source of resistance is evident when comparing the susceptible responses of 'Beauregard' and 'Porto Rico'. 'Beauregard' was highly susceptible to $M$. incognita race 3 and to $M$. javanica, but 'Porto Rico' was susceptible to $M$. incognita race 3 and resistant to $M$. javanica in our study (Table 1).

Also, levels of galling and amount of eggs per gram of root system produced in 'Beauregard' by $M$. javanica were significantly higher than in the other cultivars. 'Beauregard' is the preferred cultivar by growers for its horticultural qualities in the southern United States, representing $\approx 70 \%$ of the sweetpotatoes grown in the United States (J. Schultheis, personal communication). 'Beauregard' is also a popular parent in many breeding programs in the United States and other countries. However, because of the high susceptibility of 'Beauregard' to RKN, it should be used preferentially in crosses with resistant lines.

Jones and Dukes (1980) reported that 'Jewel' was susceptible to M. javanica. However, our results indicate that 'Jewel' is moderately resistant to $M$. javanica, since galling is not higher than $5 \%$, and the number of eggs/g was considerably lower than in 'Beauregard'. Differences in $M$. javanica isolates may account for some discrepancies between the two studies. 'Hernandez' represents $\approx 20 \%$ of the sweetpotatoes produced in North Carolina (Schultheis, J., personal communication). Its high degree of resistance to the three Meloidogyne spp. should be taken into account in future breeding programs as a possible source of resistance to RKN. 'Hernandez' is, however, a poor flowering genotype under N.C. conditions, and it may be difficult to use as a parent.

It is surprising that all five cultivars were resistant to $M$. arenaria race 2 . Meloidogyne arenaria race 2 is very aggressive on many crop species, including genotypes that are resistant to M. incognita (Davis et al., 1988, 1998). Resistance to $M$. arenaria in sweetpotato, however, has been observed previously (Giamalva et al., 1963).

The lack of correlation between necrosis and nematode infection suggests that root necrosis is not a good indicator of sweetpotato resistance to RKN. Traditionally, localized root necrosis has been associated with resistance by a hypersensitive response (Bonsi and Phills, 1979; Gentile et al., 1962). However, 
the root necrosis observed here appears to be a function of plant genotype.

Our study indicates that for a successful $\mathrm{RKN}$-resistance breeding program, breeders need to consider the nematode species most important to a production region. Our results also suggest that susceptible and resistant control sweetpotato genotypes need to be identified for each Meloidogyne species. Further studies are also needed to better understand the resistance to RKN in sweetpotato, and the impact of the different RKN host races (Hartman and Sasser, 1985) on sweetpotato genotypes.

\section{Literature Cited}

Bonsi, C.K. and B.R. Phills. 1979. Reaction of twelve sweetpotato cultivars and breeding lines to two root-knot species with 3 experimental methods. HortScience 14:539-541.

Clark C.A., P.D. Dukes, and J.W. Moyer. 1992. Diseases. In: A. Jones and J.C. Bouwkamp (eds.). Fifty years of cooperative sweetpotato research 1939-1989. Southern Coop. Ser. Bul. No. 369. Louisiana Agr. Expt. Sta. Louisiana State Univ. Agr. Ctr., Baton Rouge.

Clark, C.A. and J.W. Moyer. 1988. Compendium of sweetpotato diseases. APS Press. St. Paul, Minn.

Davis, E.L., D.M. Meyers, J.W. Burton, and K.R. Barker. 1998. Resistance to root-knot, reniform, and soybean cyst nematodes in selected breeding lines. Suppl. J. Nematol. 30(4S):530541.

Davis, E.L., J.R. Rich, G.R. Gwynn, and V. Sisson. 1988. Greenhouse evaluation of Nicotiana spp. for resistance to root-knot nematodes. Nematropica 18(2):99-107.

Daykin, M.E. and R.S. Hussey. 1985. Staining and histopathological techniques in nematology. In: Barker, K.R., C.C. Carter, and J.N. Sasser (eds.). An advanced treatise on Meloidogyne. Vol. II: Methodology. p. 39-48. North Carolina State
Univ. Graphics, Raleigh, N.C.

Dukes, P.D. and J.R. Bohac. 1992. Southern rootknot nematode: The race problem as related to breeding for resistance in sweetpotato. HortScience 27:1165. (Abstr.)

Dukes, P.D., A. Jones, and F.P. Cuthbert. 1978. W51 Root knot resistant sweetpotato germplasm. HortScience 13:201-202.

Gentile, A.G., K.A. Kimble, and G.C. Hanna. 1962. Reactions of sweetpotato breeding lines to Meloidogyne species when inoculated by an improved method. Phytopathology 52:12251226.

Giamalva, M.J., W.J. Martin, and T.P. Hernandez. 1963. Sweetpotato varietal reaction to species and races of root knot nematodes. Phytopathology 53:1187-1189.

Hartman, K.M. and J.N. Sasser. 1985. Identification of Meloidogyne species on the basis of differential host test and perineal-pattern morphology, p. 69-77. In: K.R. Barker, C.C. Carter and J.N. Sasser (eds.). An advanced treatise on Meloidogyne. Vol. II: Methodology. North Carolina State Univ. Graphics, Raleigh, N.C.

Hussey, R.S. and K.R. Barker. 1973. A comparison of methods of collecting inocula of Meloidogyne spp., including a new technique. Plant Dis. Rpt. 57:1025-1028.

Jones, A., and P.D. Dukes. 1980. Heritabilities of sweetpotato resistances to root-knot caused by Meloidogyne incognita and M. javanica.J. Amer. Soc. Hort. Sci. 105:154-156.

Jones, A., P.D. Dukes, J.M. Schalk, and M.G. Hamilton. 1989. 'Excel' sweetpotato. HortScience 24:171-172.

LaBonte, D.R., W.A. Mulkey, C.A. Clark, L.H. Rolston, J.M. Cannon, P.W. Wilson, and P.C. St. Amand. 1992. 'Hernandez' sweetpotato. HortScience 27:377.

Lawrence, G.W., C.A. Clark, and V.L. Wright. 1986. Influence of Meloidogyne incognita on resistant and susceptible sweetpotato cultivars. J. Nematol. 18(1):59-65.

Nielsen, L.W. and D.T. Pope. 1960. Resistance in sweetpotato to the internal cork virus. Plant Dis. Rptr. 44(5):342-347.

Pope, D.T., L.W. Nielsen, and N.C. Miller. 1971. 'Jewel' a new sweetpotato variety for North Carolina. N.C. Agr. Expt. Sta. Bul. 442.

Rolston, L.H., C.A. Clark, J.M. Cannon, W.M. Randle, E.G. Riley, P.W. Wilson, and M.L. Robbins. 1987. 'Beauregard' sweetpotato. HortScience 22:1338-1339.

Sasser, J.N. 1980. Root knot nematodes: A global menace to crop production. Plant Dis. 64:36-41.

Sasser, J.N. and C.C. Carter. 1985. An advanced treatise on Meloidogyne. Vol. I: Biology and control. North Carolina State Univ. Graphics.

Struble, F.B., L.S. Morrison, and H.B. Cordner. 1966. Inheritance of resistance to stem rot and root knot nematode in sweetpotato. Phytopathology 56:1217-1219.

Thies, J.A. 1999. Evaluation of regional and standard entries for reaction to southern root-knot nematode and fusarium wilt 1999. In: W.J. McLaurin (ed.). National Sweetpotato Collaborators Group progress report 1999. Lexington, $\mathrm{Ky}$.

Thomas, R.J. and C.A. Clark. 1983a. Population dynamics of Meloidogyne incognita and Rotylenchulus reniformis alone and in combination, and their effects on sweetpotato. J. Nematol. 15(2):204-211.

Thomas, R.J. and C.A. Clark. 1983b. Effects of concomitant development on reproduction of Meloidogyne incognita and Rotylenchus reniformis on sweetpotato. J. Nematol. 15(2):215-221.

Ukoskit, K., P.G. Thompson, C.E. Watson, and G.W. Lawrence. 1997. Identifying a randomly amplified polymorphic DNA (RAPD) marker linked to a gene for root-knot nematode resistance in sweetpotato. J. Amer. Soc. Hort. Sci. 122(6):818-821.

Whitehead, A.G. 1998. Plant-parasitic nematodes, their importance and control, p. 1-12. In: A.G. Whitehead (ed.). Plant nematode control. CAB Intl., Wallingford, U.K. 